\title{
The Islamic Social Reporting Index and Investment Account Holder in Islamic Banks
}

\author{
Nadia Putri ${ }^{1}$, Sepky Mardian ${ }^{2 *}$ \\ ${ }^{1,2}$ Sekolah Tinggi Ekonomi Islam SEBI, Indonesia.
}

Submitted: 28 August 2019, Accepted: 14 June 2020, Published: 18 June 2020

\begin{abstract}
This research aims to discover the influence of Corporate Social Responsibility (CSR) disclosure based on the Islamic Social Reporting (ISR) index towards Investment Account Holder (IAH) in 11 Islamic banks in Indonesia from 2013-2018. The dependent and independent variables comprise the growth of temporary Syirkah funds representing IAH and prior studies. This is an associative research with secondary data obtained from the annual report. Panel data regression was used as the analysis technique with Fixed Effect Model (FEM) chosen as the best estimation model. The result showed that the ISR index towards IAH negatively influences CSR disclosure. Furthermore, the dominant floating market customers in Indonesia tend to force Islamic banks to focus on reporting related returns, sharia-compliant transactions, and excellent service to customers rather than disclosing social factors. This trend also exists in Islamic banks in several countries, besides the absence of regulations and guidelines for social reporting standards. The social reporting guidelines issued by the Accounting and Auditing Organization for Islamic Financial Institutions (AAOIFI) are only voluntary to be implemented by Islamic banks.
\end{abstract}

Keywords: CSR disclosure; ISR index; investment account holder; Islamic banks 


\section{INTRODUCTION}

An Islamic bank is associated with the values and principles of sharia as its establishment's main factor. Therefore, in line with the presence of Islamic banking, customers anticipate exceptional and quality services. Yaqub and Bello(2011) stated that Chapra's Islamic banking model analyzes banks as organizations obligated to protect the needs of society while aiming to acquire profits and gain clients' confidence. The societal norm and value also inspired the model in Islam, where those faithful to Allah love others and give preference over themselves. Alquran, i.e., stated these values "...They love their family and prioritize their needs even when in need...... Therefore, those that practice this act are said to be successful." (Q.S.Al-Hasyr [59]:9)

Kamla and Rammal(2013) also Zafar and Sulaiman(2019), stated that Islamic banks are responsible for customers' investment, the society, and surroundings. The contribution of business towards the society is known as Corporate Social Responsibility (CSR), with its demonstration and commitment conducted through the disclosure of reliable and relevant information in the annual report (Ackers, 2014). The concept of CSR is not a new identity because Islamic banks as entities operating in accordance with Islamic principles.

CSR for Islamic banks is not only considered as a philanthropic activity for the business world in the Western concept. According to the European Commission, CSR is a concept whereby companies voluntarily integrate social and environmental concerns into their business operations and their interaction with their stakeholders (Litardi, Fiorani, \& Harb, 2019). In another concept, it is considered an implementation of the Triple Bottom Line (3P) concept with the implementation of sharia entities. CSR is no longer considered as a cost but a benefit in the context of Islamic brotherhood (ukhuwwah islamiyyah) (Litardi, Fiorani, \& Harb, 2019).

The implementation of CSR by companies aims to gain legitimacy or display social identity, which positively impacts on developing the company's perspective compared to stakeholders. The impact of CSR on businesses is to increase customer loyalty and improve company performance. The purpose of getting legitimacy from the public is explained through the legitimacy theory, while social identity theory is used to explain societal involvement with stakeholders. Islamic banks tend to provide legitimacy for both internal and external parties using the stakeholder theory. Stakeholders also adopt environmental and economic issues when making business decisions, which has ultimately impacted the long-term economic benefits of the company(Jennings \& Hoffman, 2017). CSR is implemented by companies using the institutional theory, which explains why isomorphism, also known as pressure, make organizations look similar. According to Boxenbaum and Jonsson(2017), isomorphism can be in the coercive, mimetic, and normative form. Companies have the same tendency to implement CSR because these factors are forced by regulators (coercive isomorphism). 
In act number 40 of 2007 article 74 of the Indonesian law, there is a regulation on the responsibility of companies to corporate with the surrounding environment. Subsequently, in 2012, government regulation issued number 47, which stated that the implementation of social and environmental responsibilities should be contained in the company's annual report. Government regulation also stated that there are awards and penalties applied to the company.

In the 1950s, CSR discussion started to get more attention as a subject of research, which led to several studies (Litardi, Fiorani, \& Harb, 2019; Setyaningsih \& Setiawan, 2019). Fitria and Hartanti (2010) stated, that although the practice of CSR in Indonesia is mostly conducted in manufacturing companies, following the current global trend on its practice, the banking system also started to disclose their social responsibility in the annual report even though it was still in a simple form.

There are various types of methods used to measure the performance of social responsibility, and the most commonly used is the Global Reporting Initiative (GRI) (Gustian $\&$ Faisal, 2015). Although GRI is popular, it is not adequately used in Islamic banks due to the non-existence of some important factors, namely usury, gharar, and zakat (Saridona \& Cahyandito, 2015).

Haniffa(2002) developed a model used to measure social responsibility disclosure for Islamic based institutions, including banks known as Islamic Social Reporting (ISR). The ISR was proposed as an Islamic conceptual framework to fill the gap of conventional social reporting associated with spiritual consideration. The proposed ISR aims to benefit Muslims and companies in making decisions and fulfilling their obligations to God and society. ISR was further developed by some researchers around the world and applied in different Islamic institutions. For instance, Othman, Thani, and Ghani(2009) developed and applied ISR in the capital market sector.

Sofyani, Ulum, Syam, and Wahjuni L (2012) reported ISR's practice in Malaysia and Indonesia. The study was conducted using the yearly report of 2009 and 2010, which showed that the performance level of Islamic banking in Indonesia is lower than in Malaysia. Asriati, Ulfah, and Setyorini '(2016) also replicated the previous study and found that the social performance of Islamic banking companies in Malaysia performs better than those in Indonesia. Furthermore, Fitria and Hartanti (2010) reported that social responsibility disclosure of conventional banks with the GRI method has a better score than those using ISR. However, irrespective of the fact that ISR is more relevant to Islamic bank activities, the level of social responsibility disclosure is still limited because GRI has more comprehensive and detailed indicators. 
According to Gustian and Faisal(2015), the Islamic bank that uses ISR as its disclosure index has a better result than the conventional bank with GRI. Zanariyatim, Bayinah, and Sahroni (2016) also examine Islamic banks' performance using the ISR index in their social responsibility disclosure, which showed a significant increase in scores. Zanariyatim, Bayinah, and Sahroni(2016) analyzed the finding conducted by Fitria and Hartanti(2010), which shows a conventional bank with GRI has a higher score than the Islamic bank with ISR. Zanariyatim, Bayinah, and Sahroni(2016) analyzed 11 Islamic banks from 2012 until 2014 based on the ISR index and further found out that the highest social responsibility score using the ISR index is $89,6 \%$ and the lowest is $45,8 \%$. This shows that the gap between performance scores is quite significant.

Farook (2007) conducted research to provide more information on the crucial need for social activities by Islamic banks and companies to maintain accountability and consumers' trust. Larger Islamic banks tend to contribute more in community activities, thereby, providing them with the responsibility to report the activities to all stakeholders, and primarily to the Muslim investors(Rahman \& Bukair, 2013)

O'Brien, Jarvis, and Soutar (2015) concluded that the more company increases their consumers' engagement, the greater their customers' loyalty. Farook(2007), stated that Islamic based institutions that utilize CSR easily earn legitimacy and loyalty from stakeholders.

Uddin, Hassan, and Tarique (2008) stated that CSR is an important business strategy due to its ability to grows consumers' trust. Meanwhile, Maali, Casson, and Napier (2006) reported that Muslim investors are likely to have high expectations for social activities conducted by Islamic banks. According to Solferino and Solferino(2016), stakeholders' loyalty is used to investigate the effects of a socially responsible company.

CSR practices are expected to develop continually to comply with stakeholder requirements (Ackers, 2014). El-Halaby and Hussainey (2015), reported that Islamic banks must fulfill social activities in line with sharia law. Moreover, Roziq and Rohmah(2016) stated that there is a significant influence on consumers' trust and bank information towards the number of IAH.

Consequently, according to Nguyen, Leclerc, and LeBlanc (2013), consumers' trust leads to loyalty for the company. Therefore, it is expected that the performance level of CSR disclosure based on the ISR index in Islamic bank positively influence IAH. This study tends to extend the previous research carried out by Zanariyatim, Bayinah, and Sahroni (2016) and Mubarak, Pramono, and Bayinah(2019). CSR performance based on the ISR index in eleven Islamic banks from 2012 to 2017 was analyzed using the regression methods towards temporary syirkah funds, as it represents IAH, in the annual report from 2013 to 2018. 


\section{METHOD}

This is a quantitative and descriptive research used to test the association between two or more variables (Maturidi, 2012). This study aims to determine the influence of Corporate Social Responsibility (CSR) disclosure based on the Islamic Social Reporting (ISR) index towards Investment Account Holder(IAH) in 11 Indonesia's Islamic banks.

The independent variable of this research is CSR disclosure based on the ISR index obtained from the recent studies conducted by Zanariyatim, Bayinah, and Sahroni(2016), also Mubarak, Pramono, and Bayinah (2019). Meanwhile, the Investment Account Holder is the dependent variable that represents the growth of temporary syirkah funds in Islamic banks' financial reports.

The panel data regression method was used to analyze the data measurement scale of independent and dependent variables. Panel data is a combination of time series and crosssection data using three different kinds of approaches, namely common, fixed, and random effects (Gujarati, 2003). This research used e-views 9 to process the data with the regression equation stated as follows:

$$
\text { CSRDI }=\beta 0+\beta 1 \mathrm{IAH}+" \varepsilon "
$$

Explanation:

CSRDI $=$ CSR disclosure index in Islamic bank

$\mathrm{IAH}=$ Investment Account Holder

$\varepsilon \quad=$ Error

\section{RESULTS AND DISCUSSION}

In panel data regression, the first step is to estimate the best model to use in the research. There are three types of tests to estimate the best model, namely F-Tests (Chow Test), The Hausman Test, and Lagrange Multiplier Test (LM Test)(Wati, 2018; Firdaus, 2020). The FTest (Chow) used to determine the best model between Common Effect Model and Fixed Effect Model. It shows that the probability score of cross-section $\mathrm{F}$ is 0.0252 , and it is less than the level of significance, which is 5\% $(0,05)$. This means that the Fixed Effect Model is chosen.

Furthermore, the Hausman test is used to determine the best model between the fixedeffect model and the random effect model. According to the test, the probability score of crosssection random is 0.0091 , and less than the level of significance of $5 \%(0,05)$. This means that the chosen model for this research is the Fixed Effect Model. The LM Test developed by Breusch was used to choose the best model between Random Effect and Common Effect (Wati, 2018). In this study, the LM Test was ignored because the Fixed Effect was chosen as the best model in the Chow and Hausman Test. This was followed by hypothesis testing, which 
consisted of a thorough explanation of the results of the $\mathrm{t}$-test and $\mathrm{R}^{2}$. The final test showed that Fixed Effect Model is the best estimation model with a probability score below 0.05 (5\%), which is 0.00 and $0.498 \mathrm{R}^{2}$, explained that the dependent variable significantly influences the independent variable.

Table 1. Result of the Fixed Effect Model

\begin{tabular}{ccccc}
\hline Variable & Coefficient & Std. Error & t-Statistic & Prob. \\
\hline CSRD & -2.061707 & 0.459091 & -4.490844 & 0.0000 \\
\hline C & 1.519226 & 0.312057 & 4.868423 & 0.0000 \\
\hline \multicolumn{5}{c}{ Effects Specification }
\end{tabular}

Cross-section fixed (dummy variables)

\begin{tabular}{llll} 
R - squared & 0.498227 & Mean dependent var & 0.122576 \\
\hline Adjusted R - squared & 0.396014 & S.D. dependent var & 0.268341 \\
\hline S.E. of regression & 0.208546 & Akaike info criterion & 0.134351 \\
\hline Sum squared resid & 2.348531 & Schwarz criterion & 0.263768 \\
\hline Log likelihood & 16.43359 & Hanna - Quinn criter. & 0.022964 \\
\hline F - statistic & 4.874393 & Durbin - Watson stat & 1.514554 \\
\hline Prob (F - statistic) & 0.000034 & &
\end{tabular}

According to table 1, the single-equation regression model will be present as follow:

$\mathrm{IAH}=1.519226-2.061707 \mathrm{CSRD}+\varepsilon$

The table shows that the constant value for CSR disclosure is 1.519226 . This means that in the absence of the CSR disclosed (0), IAH becomes 1.519226. The result of this research shows that there is a negative influence of CSR disclosure based on ISR index towards IAH. Therefore, CSR is disclosed as an independent variable and IAH as the dependent, with the explanation regarding the reversed result, discussed from both sides.

Nurrochmani (2010) stated that there is no regulation developed for performance measurement of CSR disclosure in Indonesia's Islamic banks. Therefore, many Islamic banks used GRI to measure their performance (Sunarto, 2016). Besides, the development of ISR as an official method in Indonesia is very slowly compared to other countries where it has gained adequate recognition as part of the report system used by sharia organization (Fitria \& Hartanti, 2010). In addition, the socio-political factors in several countries are also caused by AAOIFI standards related to social disclosure that have not become mandatory for Islamic banks and lower than stakeholder expectations '(Aribi, Arun, \& Gao, 2019).

Moreover, although Islamic banks show a high CSR disclosure based on ISR index, with an average of $65 \%$, previous research showed that the informative predicate is still far from expectation. Approximately $37 \%$ of banks are proven to be less informative and $18 \%$ not informative in CSR disclosure's detailed publicity. 
The tendency of low social disclosure by Islamic banks also occurs in several countries '(Zaki, Sholihin, \& Barokah, 2014; Aribi, Arun, \& Gao, 2019; San-Jose \& Cuesta, 2019). This is because Islamic banks are more focused on religiously accepting transactions and services to customers (Zaki, Sholihin, \& Barokah, 2014) instead of social or environmentally sound projects(San-Jose \& Cuesta, 2019). This research, therefore, explains the low disclosure made by 20 Islamic banks in 13 countries on social aspects.

Less informative predicate was achieved mostly by "younger" banks, which are new in the sharia work field. Widiastuti and Asmeldi (2016) stated that longer time-span banks achieved the majority of high numbers of Islamic Social Reporting Disclosure(ISRD).

Zanariyatim, Bayinah, and Sahroni (2016) reported that $18 \%$ of the banks are categorized as very informative, which consist of Bank Muamalat Indonesia and Bank Syariah Mandiri. Approximately $27 \%$ are categorized as informative, which consists of Bank Republik Indonesia Syariah, Bank Negara Indonesia Syariah, and Bank Syariah Bukopin, while 37\% are categorized as less informative, namely Bank Mega Syariah, Bank Central Asia Syariah, Bank BJB Syariah, and Panin Bank Syariah. The last category of banks (18\%) is not informative, which consist of Bank Victoria Syariah and Maybank Syariah.

Merina and Verawaty (2016) also stated Bank Negara Indonesia Syariah and Bank Syariah Mandiri have a high percentage for CSR disclosure based on the ISR index, while and Bank Mega Syariah has a low percentage. Meanwhile, Muhammadinah(2016) reported that Bank Syariah Mandiri and Bank Muamalat Indonesia have a high percentage, and Panin Bank Syariah is in the lowest position when measured using the GRI method. Therefore, in conclusion, the banks either used ISR or GRI to measure CSR disclosure performance.

Widiastuti and Asmeldi (2016) stated that improving media exposure and IslamicGovernance (IG) score help Islamic banks to boost their number of investors. This suggestion was based on their findings that media exposure and Islamic-Governance (IG) Score influence the ISRD and IAH.

Secondly, Karim and Affif (2006) stated that when Buchori, the head of sharia banking department in OJK was interviewed by detik finance in 2016, there were market segments of Indonesian banking, which are sharia loyalist, floating market, and conventional loyalist. Sharia loyalist is categorized as a strong belief and priority to others in the decision-making process, contrary to the conventional loyalist. Meanwhile, the floating market is the group of consumers that placed "service and return" as their priority regardless of the system (finance.detik.com, 2016).

Buchori emphasizes that consumers of Indonesia's Islamic banking are categorized as the floating market that does not bother about the system or regulation used as long as the profit 
is suited to their expectations. The floating market forces Islamic banks to focus more on shariacompliant products even though they do not have high social and environmental impacts (SanJose \& Cuesta, 2019). Factors of limited resources of Islamic banks also make them not focus on CSR. This condition is explained through slack-resource theory, which states that limited resources cause an organization to focus on providing only short-term benefits (Zafar \& Sulaiman, 2019). This is not only Islamic banks, in other Islamic related entities that report social activities due to limited resources and high costs (Yasmin, Haniffa, \& Hudaib, 2014; Ghafran \& Yasmin, 2019).

The phenomenon in Islamic banks is also one of the focuses of criticism, with a gap between Islamic banks' ideological mission and reality. They are considered very little disclose in annual reports related to social issues and poverty reduction. Training is conducted on employees to address issues related to microfinance, as well as the distribution of mudharabah and qard products (Kamla \& Rammal, 2013). This gap occurs because the teachings and values of Islam can be run by individual Muslims, although it has not been implemented with the Islamic entity as an institution(Ghafran \& Yasmin, 2019). This factor emerges from internal Islamic entities and people not ready to implement the total Islamic banking system. A floating market community is ready to share profits, but not losses (Mardian, 2015). Hidayah, Lowe, and Woods (2019), stated that there is still a high risk of pure profit-sharing in the implementation of products. Studies have also been conducted regarding the profit provided by banks, which attracted lots of consumers in the past(Roziq \& Diptyanti, 2013; Junaidi, 2015; Roziq \& Rohmah, 2016). Therefore, the use of Islamic Social Reporting (ISR) or the Global Reporting Initiative (GRI) by banks to measure CSR disclosure does not affect consumers' decision to invest for more profit.

The findings of this study differ from the legitimacy theory, which stated that the disclosure of information to the public aims to demonstrate the existence of organizations and gain legitimacy from stakeholders (Zafar \& Sulaiman, 2019). CSR disclosure is information made by a company to show its role in carrying out the Triple Bottom Line (3P) concept. With CSR, the company not only carries out the function of the pursuit of profit, it also cares for people and the environment (Litardi, Fiorani, \& Harb, 2019).

Although this research is opposed to the theories explained, it is supported by the above-listed previous findings, which shows that there is a significant negative influence of CSR disclosure based on ISR index toward IAH in Indonesia's Islamic banks from 2013-2018. 


\section{CONCLUSION}

Based on the result and discussion in the previous chapter, the following points were used to conclude this research. CSR disclosure on the ISR index negatively influences IAH, the more a company discloses CSR activity to their investor, the lower their IAH. This result is contrary to the theories supported by consumers of Islamic banks in Indonesia, which is categorized as a floating market.

However, in the Indonesian context, this result occurs due to the high floating market of Islamic banks. Customers tend to consider putting their investment in Islamic banks in the form of deposits or other temporary syirkah fund products. This condition also forced Islamic banks to focus more on the floating market. The CSR disclosure is not too high. Islamic banks also experience this condition in other countries is not high.

The Indonesian act or other regulation had no specific method of how companies need to disclose their CSR activity. Therefore, this led to the use of the GRI index by many of Indonesia's Islamic banks, which is the common method used by conventional banks, instead of ISR. Moreover, the score of CSR disclosure based on the ISR index in Indonesia is lower compared to other countries such as Malaysia.

This research has an impact on regulators' policies to make social disclosure regulations appropriate to Indonesia's conditions. It helps Islamic banks to make more efforts to increase transactions with social impact and produce more useful information in the bank management reports.

\section{BIBLIOGRAPHY}

Ackers, B. (2014). Corporate Social Responsibility Reporting : What Boards of Directors Need To Know. Corporate Board: Role, Duties and Composition, 10(3), 38-59.

Aribi, Z. A., Arun, T. G., \& Gao, S. (2019). Accountability in Islamic Financial Institution: the Role of the Shari'ah Supervisory Board Reports. Journal of Islamic Accounting and Business Research, 10(1), 98114. doi: 10.1108/JIABR-10-2015-0049.

Asriati, R., Ulfah, P., \& Setyorini, C. T. (2016). Analisis Perbandingan Komponen Islamic Social Reporting ( ISR ) Pada Bank Syariah Antara Negara Indonesia dan Malaysia. Simposium Nasional Akuntansi XIX, pp. 1-24.

Boxenbaum, E., \& Jonsson, S. (2017). Isomorphism, Diffusion and Decoupling: Concept Evolution and Theoretical Challenges in The Sage Handbook of Organizational Institutionalism. 2nd Edition. London: Sage Publications London, 79-104.

El-Halaby, S., \& Hussainey, K. (2015). The Determinants of Social Accountability Disclosure: Evidence from Islamic Banks around the World. International Journal of Business, 20(3), 202-223. 
Farook, S. (2007). On Corporate Social Responsibility of Islamic Financial Institutions. Islamic Economic Studies, 15(1), 31-46. doi: 10.1002/csr.132.

Firdaus, M. (2020) Aplikasi Ekonometrika dengan E-Views, Stata dan R. Cet. I. Bogor: IPB Press.

Fitria, S., \& Hartanti, D. (2010). Islam dan Tanggung Jawab Sosial: Studi Perbandingan Pengungkapan Berdasarkan Global Reporting Initiative Indeks dan Islamic Social Reporting Indeks. Simposium Nasional Akuntansi XIII, 1-46. doi: 10.1017/CBO9781107415324.004.

Ghafran, C., \& Yasmin, S. (2019). Ethical Governance: Insight from the Islamic Perspective and an Empirical Enquiry. Journal of Business Ethics. 1-21. doi: 10.1007/s10551019-04170-3.

Gujarati, D. N. (2003). Basic Econometrics. Singapore: McGraw-Hill, Boston.

Gustian, V., \& Faisal. (2015). Analisis Perbandingan Penggunaan GRI Indeks dan ISR Indeks dalam Pengungkapan Tanggung Jawab Sosial Perusahaan Perbankan Indonesia Tahun 2010 - 2013. Diponegoro Journal of Accounting, 4(4), 1-10.

Haniffa, R. (2002). Social Reporting Disclosure: An Islamic Perspective. Indonesian \& Accounting Research, 1(2), 128-146.

Jennings, P. D., \& Hoffman, A. J. (2017). Institutional Theory and the Natural Environment: Building Research through Tensions and Paradoxes, in The Sage Handbook of Organizational Institutionalism. 2nd Edition. London: Sage Publications London, Junaidi. (2015). Persepsi Masyarakat untuk Memilih dan Tidak Memilih Bank Syariah (Studi Kota Palopo). Jurnal Fokus Bisnis, 14(02), 1-13.

Kamla, R., \& Rammal, H. G. (2013). Social reporting by Islamic Banks: Does Social Justice Matter?.Accounting, Auditing \& Accountability Journal, 26(6), 911-945. doi: https:// doi.org/10.1108/AAAJ-03-2013-1268.

Karim,A. A., \& Affif, A. Z. (2006). Islamic Banking Consumer Behaviour in Indonesia: A Qualitative Approach, in 7th International Conference on Islamic Economics, 1-19.

Litardi, I., Fiorani, G., \& Harb, D. (2019). Corporate Social Responsibility in Islamic Culture. Comparison between Western CSR and Islamic CSR: Focus on Islamic Reporting Initiative and Islamic Financial Institution. European Journal of Islamic Finance, Special Issue, 1-7. doi: https://doi.org/10.13135/2421-2172/3065.

Maali, B., Casson, P., \& Napier, C. (2006). Social Reporting by Islamic banks. Abacus, 42(2), 266289. doi: 10.1111/j.1468-4497.2006.00200.x.

Mardian, S. (2015). Tingkat Kepatuhan Syariah di Lembaga Keuangan Syariah. Jurnal Akuntansi dan Keuangan Islam, 3(1), 57-68.

Maturidi, A. D. (2012). Metode Penelitian: TeknikInformatika. Sleman: deepublish. 
Merina, C., \& Verawaty. (2016). Analisis Komparasi Indeks Islamic Social Reporting Perusahaan Perbankan Syariah dan Perusahaan Go Publik yang Listing di Jakarta Islamic Index. Akuisisi, 12(2) 1-17.

Mubarak, D., Pramono, S., \& Bayinah, A. N. (2019). Pengungkapan Kinerja Sosial Perbankan Syariah di Indonesia. Jurnal Akuntansi dan Keuangan Islam, 7(1), 37-58.

Muhammadinah. (2016). Analisis Kelengkapan Pengungkapan Corporate Social Responsibility (CSR) Berdasarkan Indeks Global Reporting Initiative (GRI) pada Bank Umum Syariah (BUS) di Indonesia. I-Finance, 2(2), 34-53.

Nguyen, N., Leclerc, A., \& LeBlanc, G. (2013). The Mediating Role of Customer Trust on Customer Loyalty. Journal of Service Science and Management, 06(March), 96-109. doi: 10.4236/ jssm.2013.61010.

Nurrochmani, W.A. (2010). Analisis Undang-Undang dan Peraturan-Peraturan Terkait untuk Memberikan Rekomendasi Pengungkapan Tanggung Jawab Sosial di Indonesia. Universitas Indonesia.

O'Brien, I. M., Jarvis, W., \& Soutar, G. N. (2015). Integrating Social Issues and Customer Engagement to Drive Loyalty in a Service Organisation. Journal of Services Marketing, 29(6/7), 547-559. doi: 10.1108/JSM-02-2015-0085.

Othman, R., Thani, A. M., \& Ghani, E. K. (2009). Determinants of Islamic Social Reporting among Top Shariah-approved Companies in Bursa Malaysia. Research Journal of International Studies, 12(10), 4-20.

Rahman, A. A. \& Bukair, A. A. (2013). The Influence of the Shariah Supervision Board on Corporate Social Responsibility Disclosure by Islamic Banks of Gulf Co-operation Council Countries. Asian Journal of Business and Accounting, 6(2), 65-105. doi: 10.5296/jmr.v7i2.6989.

Roziq, A., \& Diptyanti, R. (2013). Variabel Penentu dalam Keputusan Memilih Tabungan Mudharabah pada Bank Syariah Mandiri Cabang Jember. JEAM, XII(1), 1-24.

Roziq, A., \& Rohmah, I. Q. (2016). Variabel Penentu dan Ekskalasi Jumlah Tabungan. Inferensi: Jurnal Penelitian Sosial Keagamaan, 10(1), 161-186.

San-Jose, L., \& Cuesta, J. (2019). Are Islamic Banks Different? The Application of the Radical Affinity Index. International Journal of Islamic and Middle Eastern Finance and Management, 12(1), 2-29. doi: 10.1108/IMEFM-07-2017-0192.

Saridona, R., \& Cahyandito, M. F. (2015). Social Performance of Indonesia Islamic Banking: Analysis of Islamic Social Reporting Index, in First International Conference of Economics and Banking (ICEB-15), 194-200. doi: 10.2991/iceb-15.2015.29.

Setyaningsih, R., \& Setiawan, D. (2019). Recent Development of Islamic Corporate Social Responsibility. Etikonomi, 18(2), 287-302. 
Sofyani, H., Ulum, I., Syam, D., \& Wahjuni L, S. (2012) 'Islamic Social Reporting Index Sebagai Model Pengukuran Kinerja Sosial Perbankan Syariah (Studi Komparasi Indonesia dan Malaysia). Jurnal Dinamika Akuntansi, 4(1), 36-46.

Solferino, N., \& Solferino, V. (2016). The Corporate Social Responsibility Is just a Twist in a Mobius Strip. Economics, 10, 1-25. doi: 10.5018/economics-ejournal.ja.2016-15.

Sunarto, C. N. (2016). Shariah Governance dalam Pengungkapan Islamic Social Reporting Index dan Global Reporting Index pada Perbankan Syariah Periode 2010-2013. Jurnal Ekonomi dan Bisnis Islam, 2(1), 30-57.

Uddin, M. B., Hassan, M. R., \& Tarique, K. M. (2008). Three Dimensional Aspects of Corporate Social Responsibility. Daffodil International University Journal of Business and Economics, $3(1), 199-212$.

Wati, L. N. (2018). Metodologi Penelitian Terapan: Aplikasi SPSS, EVIEWS, Smart PLS dan AMOS. Edisi Revisi. Bekasi: Pustaka Amri.

Widiastuti, E., \& Asmeldi, M. (2016). Faktor Non Financial dan Islamic Social Reporting Disclosure Perbankan Syariah Indonesia. Jurnal Akuntansi dan Keuangan Islam, 4(2), 183-214.

Yaqub, J. O., \& Bello, H. T. (2011). Applicability of Chapra's Model of Islamic Banking in Nigeria. European Scientific Journal, 8(15), 72-85.

Yasmin, S., Haniffa, R., \& Hudaib, M. (2014). Communicated Accountability by Faith-Based Charity Organization. Journal of Business Ethics, 122(1), 103-123. doi: 10.1007/s10551-013-1759-2. Zafar, M. B., \& Sulaiman, A. A. (2019). Corporate Social Responsibility and Islamic Banks: a Systematic Literature Review. Management Review Quarterly, 69(2), 159-206.

Zaki, A., Sholihin, M., \& Barokah, Z. (2014). The Association of Islamic Bank Ethical Identity and Financial Performance: Evidence from Asia. Asian Journal of Business Ethics, 3, 97-110. doi: 10.1007/s13520-014-0034-7.

Zanariyatim,A., Bayinah, A. N., \& Sahroni, O. (2016). Analisis Pengungkapan Corporate Social Responsibility (CSR) Bank Umum Syariah Berdasarkan Islamic Social Reporting Indeks (Indeks ISR), in Tantangan Pengembangan Ilmu Akuntansi, Inklusi Keuangan dan Kontribusinya Terhadap Pembangunan Ekonomi Berkelanjutan. Tangerang Selatan: Program Studi Akuntansi S1 Fakultas Ekonomi Universitas Pamulang, 1-20.

\section{Internet}

finance.detik.com. (2016). Ini Alasan Nasabah Syariah Perbankan Syariah RI Masih Minim. Https://Finance.Detik.Com. Retrieved from https://finance.detik.com/moneter/d3151148 /ini-alasan-nasabah-syariah-perbankan-syariah-ri-masih-minim 